\title{
LABA/LAMA Fixed Dose Combination in Chronic Obstructive Pulmonary Disease: The Impact on Health-Related Quality of Life
}

\author{
Marina Labor ${ }^{\mathrm{a}}$ Fulvio Braido $^{\mathrm{b}} \quad$ Andras Bikov $^{\mathrm{c}}$ Lies Lahousse $^{\mathrm{d}}$ \\ Paola Rogliani $^{e} \quad$ Ilaria Baiardini ${ }^{f}$
}

${ }^{a}$ Department of Pulmonology, University Hospital Center Osijek, Osijek, Croatia, Faculty of Medicine, J.J. Strossmayer University of Osijek, Osijek, Croatia; ${ }^{b}$ Department of Internal Medicine, Respiratory Diseases and Allergy Clinic, University of Genova, Azienda Policlinico IRCCs San Martino, Genoa, Italy; ${ }^{\mathrm{C} N I H R}$ Manchester Clinical Research Facility, Manchester University NHS Foundation Trust, Manchester, UK; ${ }^{\mathrm{d}}$ Department of Bioanalysis, Faculty of Pharmaceutical Sciences, Ghent University, Ghent, Belgium; ' Dipartimento di Medicina Sperimentale e Chirurgia Università di Roma "Tor Vergata," Roma, Italy; ${ }^{~}$ Department of Biomedical Sciences, Humanitas University, Milano, Italy

\section{Keywords}

Chronic obstructive pulmonary disease treatment . Long-acting beta 2-agonists /long-acting muscarinic antagonists fixed dose combinations · Randomized controlled trials $\cdot$ Health-related quality of life .

Patient reported outcomes

\begin{abstract}
Background: While fixed dose combinations (FDCs) of longacting beta 2-agonists (LABAs) and long-acting muscarinic antagonists (LAMAs) are increasingly tested on their efficacy in improving lung function, their effectiveness on Patient Reported Outcomes (PROs) such as Health Related Quality of Life (HRQoL) and Health Status (HS) deserve more attention. Objectives: To review current available evidence about the treatment effect of fixed LABA/LAMA FDCs on HRQoL. Methods: A systematic literature search for randomized controlled trials (RCTs) about the impact of LABA/LAMA FDCs
\end{abstract}

\section{KARGER}

(c) 2018 S. Karger AG, Basel

E-Mail karger@karger.com

www.karger.com/res versus placebo, LABA or LAMA or LABA/ICS on HRQoL in Chronic obstructive pulmonary disease (COPD) patients has been performed. Results: Twenty-eight RCTs ( $n=32,165$ COPD patients) investigating the impact of fixed LABA/ LAMA combinations on HRQoL were included. Using the St George' s Respiratory Questionnaire, 27 out of 28 trials assessed HRQoL. LABA/LAMA FDCs significantly improved HRQoL versus placebo in 9 out of 11 trials, while change when compared to other LABA or LAMA monocomponents was significantly better in 11 out 24. In 5 out of 6 RCTs having LABA/ICS as comparators, LABA/LAMA FDC had a similar effect and only 1 showed significant improvement in HRQL compared to LABA/ICS FDC. Conclusion: LABA/LAMA FDCs may be helpful in improving HRQoL, but because of the heterogeneity of performed trials, strong conclusions cannot be drawn. Moreover, due to the different molecule properties,

L.L., P.R., and I.B. contributed equally to this paper. 
treatment schedule, and device characteristics of each FDC, a generalized judgment seems inappropriate. Pragmatic trials powered to detect real-life differences in HRQoL and head-to-head comparison are needed to guide clinical practice in terms of PROs.

(c) 2018 S. Karger AG, Basel

\section{Introduction}

Chronic obstructive pulmonary disease (COPD) is a progressive disorder that requires long-term, regular use of inhaled medications to control symptoms. Maintenance therapy with long-acting bronchodilators is the cornerstone of therapy for GOLD groups $B, C$ and D [1] patients. Both long-acting beta 2-agonist (LABA) and long-acting muscarinic antagonist (LAMA) are effective as monotherapies and have acceptable safety profiles [2, 3]. They also significantly improve Health Related Quality of Life (HRQoL) and Health Status (HS), but in many cases, this change is below the Minimally Important Difference (MID) [4]. Symptomatic, not adequately controlled patients on a single long-acting bronchodilator, may benefit from the treatment of the combined use of 2 bronchodilators (LABA/LAMA) with distinct mechanisms of action. Therefore, combining these 2 drugs into a single inhaler, LABA/LAMA fixed dose combination (FDC) is the preferred next step in COPD treatment [1]. It has been demonstrated that they provide superior bronchodilation and reduce hyperinflation compared with the individual drugs, with a lower risk of side effects than any increased dose of either single drug [1, 5-7]. Furthermore, LABAs might enhance the bronchodilator effect of LAMAs through decreasing the release of acetylcholine, thereby enhancing the bronchial smooth muscle relaxation induced by LAMA, while LAMAs might amplify the direct stimulatory effect of LABAs on smooth muscle by reducing bronchoconstriction effects of acetylcholine $[8,9]$. So far, 5 LABA/LAMA FDCs are available in Europe (Glycopyrronium/Indacaterol, Umeclidinium/Vilanterol, Tiotropium/Olodaterol, Aclidinium/ Formoterol, Glycopyrrolate/Formoterol). Step-up on a LABA/LAMA FDC is now an important therapeutic option, providing patients more efficient drug delivery, thus improving adherence [1]. Clinical trials have shown a greater effect on exacerbation rates for LAMA treatment versus LABA treatment $[10,11]$ LABA/LAMA combination provided improvements in lung function, lower use of rescue medication, better HS, and less COPD symptoms [11-13]. Previous studies with LABA/LAMA fo- cused primarily on the improvement in lung function, and less attention has been paid to HRQoL and HS [1416]. However, lung function improvement does not correlate strongly with HRQoL and HS, although functional improvement of clinical parameters implies such a relationship [4]. Patient Reported Outcomes (PROs) [17], such as HRQoL and HS, represent the patient perspective and therefore a relevant outcome. Furthermore, the first head-to-head comparison trial of 2 different LABA/ LAMA FDCs showed that different compounds can have a different impact on HRQoL [17]. In this light, the aim of this systematic review was to examine and summarize current available evidence about the treatment effect of fixed LABA/LAMA FDCs on HRQoL.

\section{Methods}

A comprehensive literature search for randomized controlled trials (RCTs) published in English and looking at the impact of LABA/LAMA FDCs in patients with COPD. The search was performed in PubMed, Embase, Scopus and Google Scholar through to December 2017. The terms "aclidinium," "formoterol," "glycopyrronium," "glycopyrrolate," "indacaterol," "olodaterol," "salmeterol," "tiotropium," "umeclidinium," and "vilanterol" were searched for the FDCs, and the terms "chronic obstructive pulmonary disease" OR "COPD” were searched for the disease. Studies reporting the impact of LABA/LAMA FDCs versus LABAs or LAMAs or LABA/inhaled corticosteroid (ICS) FDCs on quality of life/health status were included in this systematic review. Two reviewers independently checked the relevant studies identified from literature searches and databases. The evaluated LABA/ LAMA FDCs were as follows: Aclidinium/Formoterol (ACL/ FOR) 400/12 $\mu \mathrm{g}$ twice daily, Indacaterol/Glycopyrronium (IND/ GLY) $110 / 50 \mu \mathrm{g}$ once daily or Indacaterol/Glycopyrrolate 27.5/15.6 $\mu \mathrm{g}$ twice daily, Glycopyrrolate/Formoterol (GLY/FOR) $8 / 9.6 \mu \mathrm{g}$ ( 2 inhalations twice daily), Tiotropium/Olodaterol (TIO/ OLO) $5 / 5 \mu \mathrm{g}$ once daily, Umeclidinium/Vilanterol (UME/VIL) $62.5 / 25 \mu \mathrm{g}$ once daily. For each study, the following issues were considered:

- Changes in HRQoL/HS total scores from baseline to the end of the study in each group;

- Differences in HRQoL/HS score changes between the study treatment and comparators;

- Percentage of patients who achieved the MID at the end of the study in each group;

- Change in HRQoL/HS factorial scores from baseline to the end of the study in the active group.

\section{Results}

A total of 22 articles reporting 28 RCTs evaluated the impact of fixed LABA/LAMA combinations on HRQoL by means of validated questionnaires: 4 with ACL/FOR, 
Table 1. Characteristics of the tools that were used in the selected RCTs

\begin{tabular}{|c|c|c|c|c|}
\hline $\begin{array}{l}\text { St. George's Respiratory } \\
\text { Questionnaire (SGRQ) }[19,20]\end{array}$ & 50 & $\begin{array}{l}\text { Symptoms } \\
\text { Activity } \\
\text { Impact }\end{array}$ & $\begin{array}{l}\text { Total and factorial scores range from } 0 \text { to } 100 \text {, } \\
\text { with higher scores indicating more limitations }\end{array}$ & $\geq 4[21]$ \\
\hline $\begin{array}{l}\text { COPD Assessment TEST } \\
(\text { CAT })[43,44]\end{array}$ & 8 & Impact & $\begin{array}{l}\text { Range of CAT scores from } 0-40 \text {. Higher scores } \\
\text { denote a more severe impact of COPD on a } \\
\text { patient's life. Scores of } 0-10,11-20,21-30 \text { and } \\
31-40 \text { represent mild, moderate, severe or very } \\
\text { severe clinical impact [ } 4 \text { ] }\end{array}$ & $\geq 2[45]$ \\
\hline EuroQoL-5D (EQ-5D) [46] & $\begin{array}{l}5 \text { questions }+ \\
1 \text { VAS }\end{array}$ & $\begin{array}{l}\text { Mobility, } \\
\text { self-care, } \\
\text { usual activities, } \\
\text { pain/discomfort } \\
\text { anxiety/depression }\end{array}$ & $\begin{array}{l}\text { Three possible answers for each item }(1=\text { no } \\
\text { problem, } 2=\text { moderate problem, } 3=\text { severe } \\
\text { problem) } \\
\text { A summary index with a maximum score of } 1 \\
\text { (indicates full health) can be derived from the } \\
\text { five dimensions. The VAS indicates the general } \\
\text { health status on a continuous scale with } \\
100 \text { indicating the best health status }\end{array}$ & $0.108[47]$ \\
\hline
\end{tabular}

MID, minimally important difference; VAS, Visual Analogue Scale.

3 with GLY/FOR, 8 RCTs with IND/GLY, 4 with TIO/ OLO, and 9 with UME/VIL. One study used the only the CAT to assess HRQoL [18], while the St George's Respiratory Questionnaire (SGRQ) [19-21] was used in 27 RCTs [22-42]. Three RCTs $[23,29,37]$ also used the COPD Assessment Test (CAT) [43-45], and 2 papers $[38,39]$ used the EQ-5D [46, 47]. Table 1 reports the characteristics of the tools that were used in the selected RCTs. An overall population of 32,165 patients were randomized and 20,414 completed the studies. The duration of the studies ranged from 8 to 64 weeks. The characteristics of the selected trials are described in Table 2 . The change in SGRQ total score from baseline to the end of the study in each arm of the studies, the difference in SGRQ total score for LABA/LAMA and comparators, the percentage of patients who achieved the MID in each arm, and the change in SGRQ factorial scores are shown in Table 3. Figure 1 reports the number of trials in which the differences between LABA/ LAMA and each comparator were significant and not significant.

Here below, we report the key results of the data shown in Table 2 and 3. ACL/FOR 400/12 significantly improved SGRQ when compared to placebo in the AUGMENT [25] study and in its extension [22] in patients with moderate to severe COPD according to GOLD 2014, 40 years old or older. On the contrary, in the
ACLIFORM-COPD study, enrolling patients with moderate severe COPD according to GOLD 2010, no differences in HRQoL scores were found after 24 weeks of treatment with ACL/FOR $400 / 12$ or placebo [24]. Improvement of SGRQ after treatment with ACL/FOR $400 / 12$ was never found superior to those with monotherapies $[22,25]$ or to other ACL/FOR dosages [24]. The percentage of patients who reached the MID with ACL/ FOR 400/12 treatment was significantly higher than placebo in the study of D'Urzo et al. [25] but was not higher than comparators or placebo in the other studies. In addition to SGRQ, CAT has been used in the study of Vogelmeier et al. [23] in which the MID was achieved in both ACL/FOR 400/12 and in SAL/FLU 50/500 at the end of the study, without any significant differences between groups enrolled with a CAT score $\geq 10$.

GLY/FOR was superior to monotherapy with GLY $[26,27]$ and to placebo [26] but never superior to FOR in 2 studies including moderate to severe COPD patients according to ATS guidelines [26, 27]. The percentage of them who reached the MID with GLY/FOR was significantly higher compared to placebo [26] or GLY $[26,27]$.

IND/GLY was superior to monotherapy with GLY [32, 30], TIO [31, 32, 37], placebo [30, 31, 37] but not superior to IND $[30,31]$ in patients with moderate COPD according ATS guidelines 2014 (FEV1 - 50-70\% predicted) and MRC $\geq 1$ [37] or moderate/severe COPD according to 
Table 2. Studies characteristics

\begin{tabular}{|c|c|c|c|c|c|c|c|c|c|}
\hline Notes & $\begin{array}{l}\text { Study, reference, } \\
\text { and year }\end{array}$ & $\begin{array}{l}\text { Trial Number } \\
\text { Identifier }\end{array}$ & $\begin{array}{l}\text { Study } \\
\text { duration, } \\
\text { weeks }\end{array}$ & $\begin{array}{l}\text { Randomized } \\
\text { patients (patients } \\
\text { who completed } \\
\text { the study) }\end{array}$ & FDCs, $\mu \mathrm{g}$ & $\begin{array}{l}\text { Comparators, } \mu g \\
\text { (vs. LABA or } \\
\text { LAMA; vs. } \\
\text { ICS/LABA) }\end{array}$ & SGRQ & CAT & $\begin{array}{l}\text { Primary } \\
\text { endpoint }\end{array}$ \\
\hline $\begin{array}{l}\text { 6-month AUGMENT } \\
\text { extension study }\end{array}$ & $\begin{array}{l}\text { D’Urzo et al. } \\
{[22], 2017}\end{array}$ & NCT01572792 & 28 & $921(780)$ & $\begin{array}{l}\text { ACL/FOR } \\
400 / 12\end{array}$ & $\begin{array}{l}\text { ACL/FORM } 400 / 6, \\
\text { ACL } 400, \text { FOR } 12, \\
\text { Placebo }\end{array}$ & $\mathrm{X}$ & & No \\
\hline AFFIRM & $\begin{array}{l}\text { Vogelmeier et al. } \\
{[23], 2016}\end{array}$ & NCT01908140 & 24 & $933(788)$ & $\begin{array}{l}\text { ACL/FOR } \\
400 / 12\end{array}$ & SAL/FLU 50/500 & $\mathrm{X}$ & $\mathrm{X}$ & No \\
\hline ACLIFORM-COPD & $\begin{array}{l}\text { Singh et al. } \\
{[24], 2014}\end{array}$ & NCT01462942 & 24 & $1,729(1,526)$ & $\begin{array}{l}\text { ACL/FOR } \\
400 / 12\end{array}$ & $\begin{array}{l}\text { ACL/FORM 400/6, } \\
\text { ACL 400, FOR 12, } \\
\text { Placebo }\end{array}$ & $\mathrm{X}$ & & No \\
\hline AUGMENT COPD & $\begin{array}{l}\text { D'Urzo et al. } \\
{[25], 2014}\end{array}$ & NCT01437397 & 24 & $1,692(1,322)$ & $\begin{array}{l}\text { ACL/FOR } \\
400 / 12\end{array}$ & $\begin{array}{l}\text { ACL/FORM } 400 / 6, \\
\text { ACL } 400, \text { FOR } 12, \\
\text { placebo }\end{array}$ & $\mathrm{X}$ & & No \\
\hline Pinnacle 1 & $\begin{array}{l}\text { Martinez et al. } \\
{[26], 2017}\end{array}$ & NCT01854645, & 24 & $2,013(1,695)$ & $\begin{array}{l}\text { GLY/FOR } \\
18 / 9.6\end{array}$ & $\begin{array}{l}\text { GLY 18, FOR 9.6, } \\
\text { TIO } 18 \text { placebo }\end{array}$ & $\mathrm{X}$ & & No \\
\hline Pinnacle 2 & & NCT01854658 & 24 & $1,615(1,308)$ & $\begin{array}{l}\text { GLY/FOR } \\
18 / 9.6\end{array}$ & $\begin{array}{l}\text { GLY 18, FOR 9.6, } \\
\text { placebo }\end{array}$ & $\mathrm{X}$ & & No \\
\hline $\begin{array}{l}\text { Pinnacle } 3: 28 \text {-weeks } \\
\text { Pinnacle } 1 \text { and } \\
2 \text { extension study }\end{array}$ & $\begin{array}{l}\text { Hanania et al. } \\
{[27], 2017}\end{array}$ & NCT01970878 & 52 & $892(778)$ & $\begin{array}{l}\text { GLY/FOR } \\
18 / 9.6\end{array}$ & $\begin{array}{l}\text { GLY 18, FOR 9.6, } \\
\text { TIO } 18\end{array}$ & $\mathrm{X}$ & & No \\
\hline Notes & $\begin{array}{l}\text { Study, reference, } \\
\text { and year }\end{array}$ & $\begin{array}{l}\text { Trial Number } \\
\text { Identifier }\end{array}$ & $\begin{array}{l}\text { Study } \\
\text { duration, } \\
\text { weeks }\end{array}$ & $\begin{array}{l}\text { Randomized } \\
\text { patients (patients } \\
\text { who completed } \\
\text { the study) }\end{array}$ & FDCs, $\mu \mathrm{g}$ & $\begin{array}{l}\text { Comparators, } \mu \mathrm{g} \\
\text { (vs. LABA or } \\
\text { LAMA; vs. } \\
\text { ICS/LABA) }\end{array}$ & $\begin{array}{l}\text { Quality } \\
\text { of life } \\
\text { (SGRQ) }\end{array}$ & CAT & $\begin{array}{l}\text { Primary } \\
\text { endpoint }\end{array}$ \\
\hline FLAME & $\begin{array}{l}\text { Wedzicha et al. } \\
{[28], 2016}\end{array}$ & NCT01782326 & 52 & $3,362(2,760)$ & $\begin{array}{l}\text { IND/GLY } \\
110 / 50\end{array}$ & SAL/FLU 50/500 & $\mathrm{X}$ & & No \\
\hline LANTERN & $\begin{array}{l}\text { Zhong et al. } \\
{[29], 2015}\end{array}$ & NCT01709903 & 26 & $744(676)$ & $\begin{array}{l}\text { IND/GLY } \\
110 / 50\end{array}$ & SAL/FLU 50/500 & $\mathrm{X}$ & $\mathrm{X}$ & No \\
\hline $\begin{array}{l}\text { FLIGHT1 and } \\
\text { FLIGHT2 }\end{array}$ & $\begin{array}{l}\text { Mahler et al. } \\
{[30], 2015}\end{array}$ & $\begin{array}{l}\text { NCT01727141, } \\
\text { NCT01712516 }\end{array}$ & 12 & $\begin{array}{l}1,042(951) \\
1,001(934)\end{array}$ & $\begin{array}{l}\text { IND/GLY } \\
27.5 / 15.6\end{array}$ & $\begin{array}{l}\text { IND 27.5, GLY } \\
\text { 15.6, Placebo }\end{array}$ & $\mathrm{X}$ & & No \\
\hline SHINE & $\begin{array}{l}\text { Bateman et al. } \\
{[31], 2013}\end{array}$ & NCT01202188 & 26 & $2,144(, 1910)$ & $\begin{array}{l}\text { IND/GLY } \\
110 / 50\end{array}$ & $\begin{array}{l}\text { GLY 50, IND 150, } \\
\text { TIO 18, Placebo }\end{array}$ & $\mathrm{X}$ & & No \\
\hline SPARK & $\begin{array}{l}\text { Wedzicha et al. } \\
\text { [32], } 2013\end{array}$ & NCT01120691 & 64 & $2,224(1,667)$ & $\begin{array}{l}\text { IND/GLY } \\
110 / 50\end{array}$ & GLY 50, TIO 18 & $\mathrm{X}$ & & No \\
\hline ILLUMINATE & $\begin{array}{l}\text { Vogelmeier et al. } \\
{[33], 2013}\end{array}$ & NCT01315249 & 26 & $523(432)$ & $\begin{array}{l}\text { IND/GLY } \\
110 / 50\end{array}$ & SAL/FLU 50/500 & $\mathrm{X}$ & & No \\
\hline- & $\begin{array}{l}\text { Molino et al. } \\
{[34], 2017}\end{array}$ & & 52 & $40(35)$ & $\begin{array}{l}\text { IND/GLY } \\
110 / 50\end{array}$ & TIO 2.5 & $\mathrm{X}$ & & No \\
\hline Notes & $\begin{array}{l}\text { Study, reference, } \\
\text { and year }\end{array}$ & $\begin{array}{l}\text { Trial Number } \\
\text { Identifier }\end{array}$ & $\begin{array}{l}\text { Study } \\
\text { duration, } \\
\text { weeks }\end{array}$ & & FDCs, $\mu \mathrm{g}$ & Comparators, $\mu \mathrm{g}$ & $\begin{array}{l}\text { Quality } \\
\text { of life } \\
\text { (SGRQ) }\end{array}$ & CAT & $\begin{array}{l}\text { Primary } \\
\text { endpoint }\end{array}$ \\
\hline OTEMTO & $\begin{array}{l}\text { Buhl et al. } \\
{[35], 2015}\end{array}$ & $\begin{array}{l}\text { NCT01431274, } \\
\text { NCT01431287 }\end{array}$ & $\begin{array}{l}52 \\
52\end{array}$ & $2,624(2,262)$ & $\begin{array}{l}\text { TIO/OLO } \\
5 / 5\end{array}$ & $\begin{array}{l}\text { TIO/OLO } 2.5 / 5 \text {, } \\
\text { TIO } 5, \text { TIO } 2.5, \\
\text { OLO } 5\end{array}$ & $\mathrm{X}$ & & No \\
\hline - & $\begin{array}{l}\text { Singh et al. } \\
{[36], 2015}\end{array}$ & $\begin{array}{l}\text { NCT01964352, } \\
\text { NCT02006732 }\end{array}$ & $\begin{array}{l}12 \\
12\end{array}$ & $\begin{array}{l}814(761) \\
809(764)\end{array}$ & $\begin{array}{l}\text { TIO/OLO } \\
5 / 5\end{array}$ & $\begin{array}{l}\text { TIO 5, TIO/OLO } \\
2.5 / 5, \text { Placebo }\end{array}$ & $\mathrm{X}$ & & yes \\
\hline- & $\begin{array}{l}\text { Kerwin et al. } \\
{[37], 2017}\end{array}$ & NCT01899742 & 12 & $494(461)$ & $\begin{array}{l}\text { UME/VIL } \\
62.5 / 25\end{array}$ & TIO 18 & $\mathrm{X}$ & $\mathrm{X}$ & No \\
\hline
\end{tabular}


Table 2. (continued)

\begin{tabular}{|c|c|c|c|c|c|c|c|c|c|}
\hline Notes & $\begin{array}{l}\text { Study, reference, } \\
\text { and year }\end{array}$ & $\begin{array}{l}\text { Trial Number } \\
\text { Identifier }\end{array}$ & $\begin{array}{l}\text { Study } \\
\text { duration, } \\
\text { weeks }\end{array}$ & & FDCs, $\mu \mathrm{g}$ & Comparators, $\mu \mathrm{g}$ & $\begin{array}{l}\text { Quality } \\
\text { of life } \\
\text { (SGRQ) }\end{array}$ & CAT & $\begin{array}{l}\text { Primary } \\
\text { endpoint }\end{array}$ \\
\hline- & $\begin{array}{l}\text { Donohue et al. } \\
\text { [39], } 2015\end{array}$ & $\begin{array}{l}\text { NCT01817764, } \\
\text { NCT01879410 }\end{array}$ & $\begin{array}{l}12 \\
12\end{array}$ & $\begin{array}{l}707(634) \\
700(638)\end{array}$ & $\begin{array}{l}\text { UME/VIL } \\
62.5 / 25\end{array}$ & SAL/FLU 25/250 & $\mathrm{X}$ & $\begin{array}{l}X \\
\text { (EQ-5D) }\end{array}$ & No \\
\hline- & $\begin{array}{l}\text { Maleki-Yazdi et al. } \\
\text { [41], } 2014\end{array}$ & NCT01777334 & 24 & 905 (789) & $\begin{array}{l}\text { UME/VIL } \\
62.5 / 25\end{array}$ & TIO 18 & $\mathrm{X}$ & & No \\
\hline- & $\begin{array}{l}\text { Donohue et al. } \\
{[42], 2013}\end{array}$ & NCT01313650 & 24 & $1,536(1,178)$ & $\begin{array}{l}\text { UME/VIL } \\
62.5 / 25\end{array}$ & $\begin{array}{l}\text { UME } 62.5 \text {, VIL } 25 \text {, } \\
\text { placebo }\end{array}$ & $\mathrm{X}$ & & No \\
\hline
\end{tabular}

ACL, aclidinium bromide; FDC, fixed-dose combination; FLU, fluticasone fumarate; FOR, formoterol fumarate; GLY, glycopyrronium or glycopyrrolate; ICS, inhaled corticosteroid; IND, indacaterol; LABA, long-acting $\beta_{2}$-agonist; LAMA, long-acting muscarinic antagonist; OLO, olodaterol; SAL, salmeterol; SGRQ, St. George's Respiratory Questionnaire; TIO, tiotropium; UME, umeclidinium; VIL, vilanterol.

GOLD 2011 [30] or 2008 [31]. Of note, another study showed no significant difference compared to TIO [34]. IND/GLY was superior to SAL/FLU 50/500 in the study of Wedzicha et al. [28] enrolling COPD patients with mMRC $>2$ and $\mathrm{FEV}_{1} 25-60 \%$ predicted but not in the studies performed by Vogelmeier et al. [33] and Zhong et al. [29] including, respectively, COPD patients stages $2-3$ according GOLD 2009 and stages 2-3 GOLD 2010 and MRC $\geq 2$. The percentage of patients who reached the MID with GLY/ IND was significantly higher compared to that of the placebo [30], GLY [30, 36], SAL/FLU 50/500 [28] or TIO [31]. The use of CAT as secondary outcome measure to assess HRQoL [29] showed no difference in patients treated with IND/GLY 110/50 and SAL/FLU 50/500.

TIO/OLO significantly improved SGRQ when compared to monotherapies [35, 36] and placebo [36], but no differences emerged in comparison with its different dosages $[35,36]$ in patients with COPD stages $2-4$ according GOLD 2006. A significantly higher percentage of patients treated with TIO/OLO compared to monotherapies with LABA or LAMA $[35,36]$ and placebo $[35,36]$ achieved MID, whereas no differences emerged in comparison to TIO/OLO 2.5/5 [35, 36].

UME/VIL was never found to be superior to comparators in patients with COPD according to ATS 2004, MRC >1, FEV1 20-70\% predicted [37], COPD with FEV1 $-30-70 \%$ predicted, MRC $\geq 2$, [38], and COPD

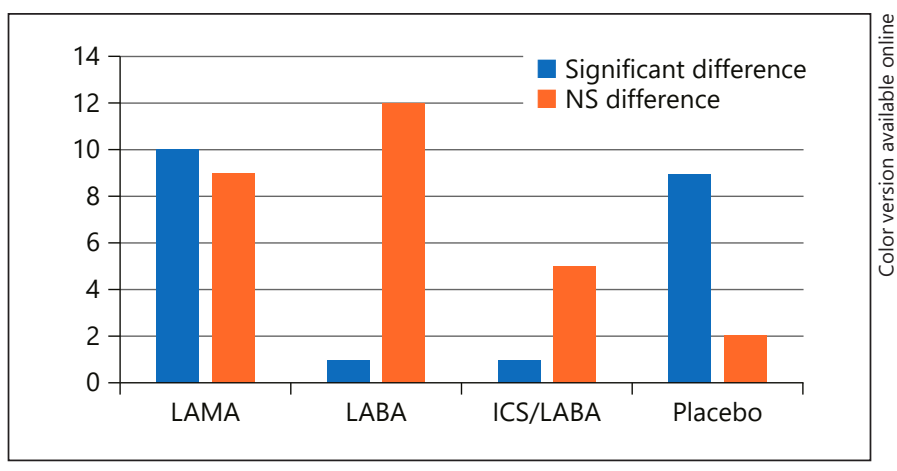

Fig. 1. HRQoL differences between LAMA/LABA versus comparators.

with FEV1 30-70\%, MRC $\geq 2[39,42]$ and at least 1 exacerbation in the previous year [42], (both in improving SGRQ scores and in percentage of patients who achieved the MID) [37-40], except for TIO [41] and placebo [39]. The studies of Kerwin [37] and Feldman [18] evaluated HRQoL using the CAT. At the end of the study, no significant difference was found between UME/VIL and TIO [37], TIO/OLO [18] in CAT change or in the percentage of patients who achieved MID. Moreover, the assessment of HRQoL by means of EQ-5D [46], did not detect a superiority of UME/VIL compared to SAL/FLU 25/500 [38-39]. 


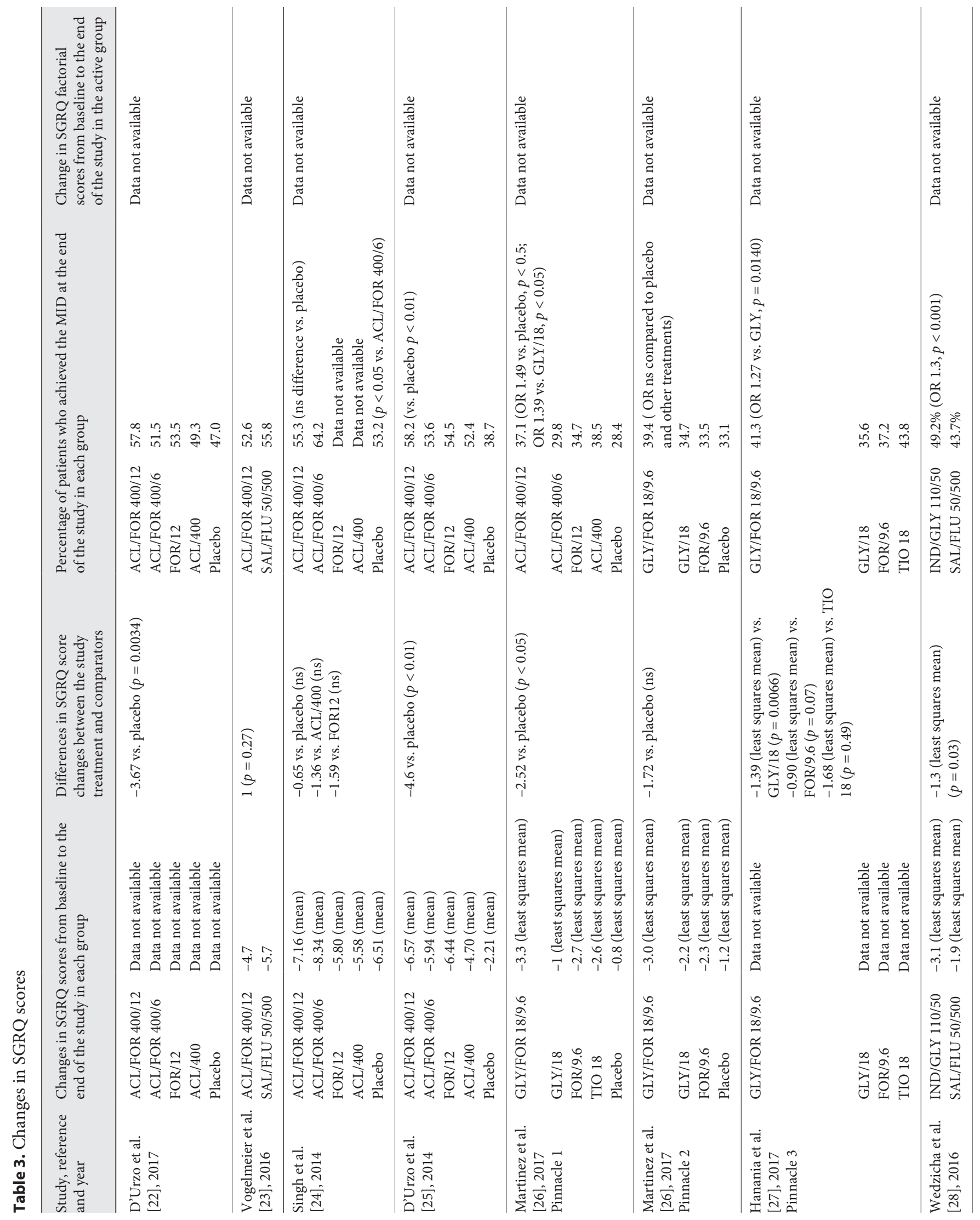




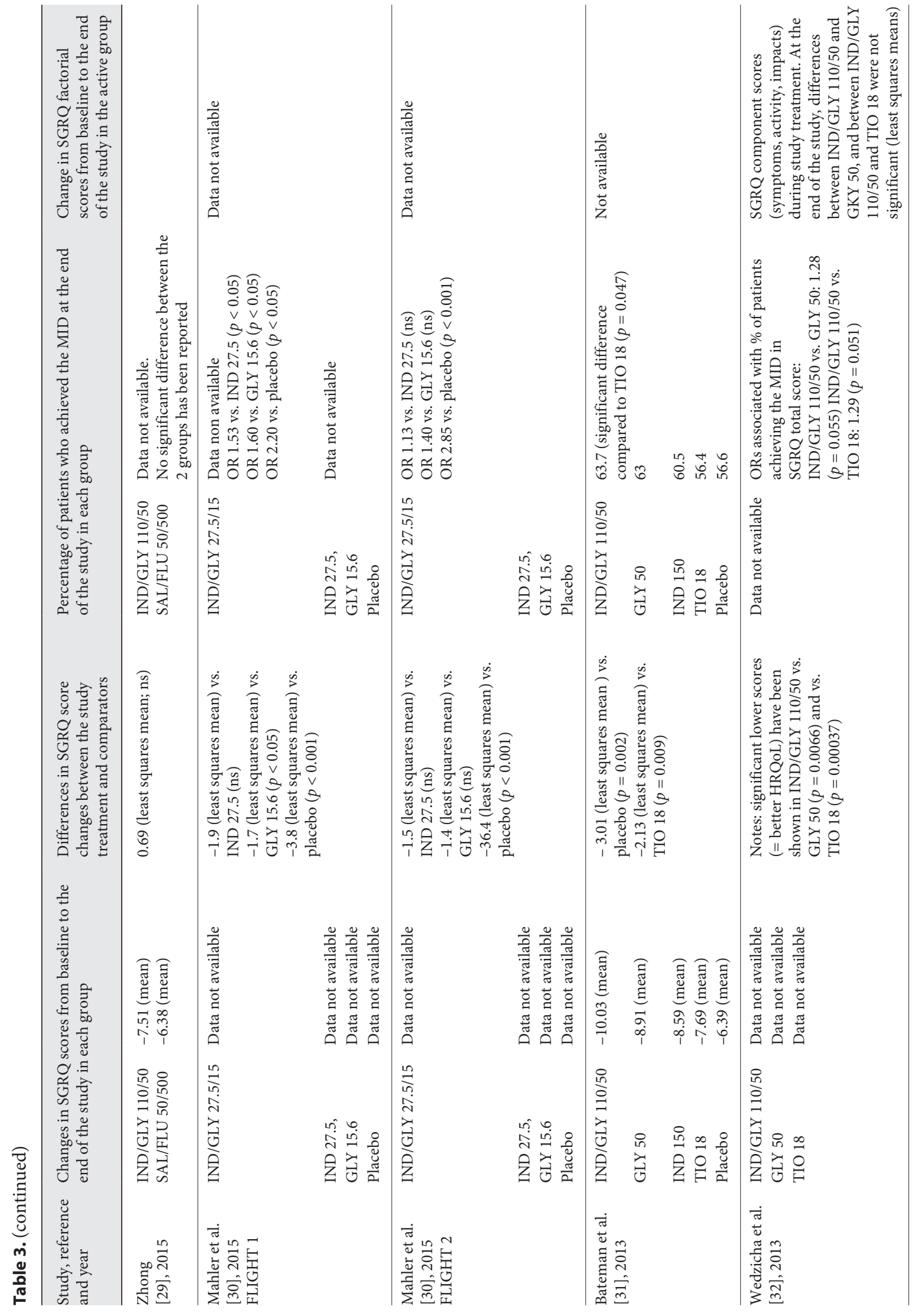




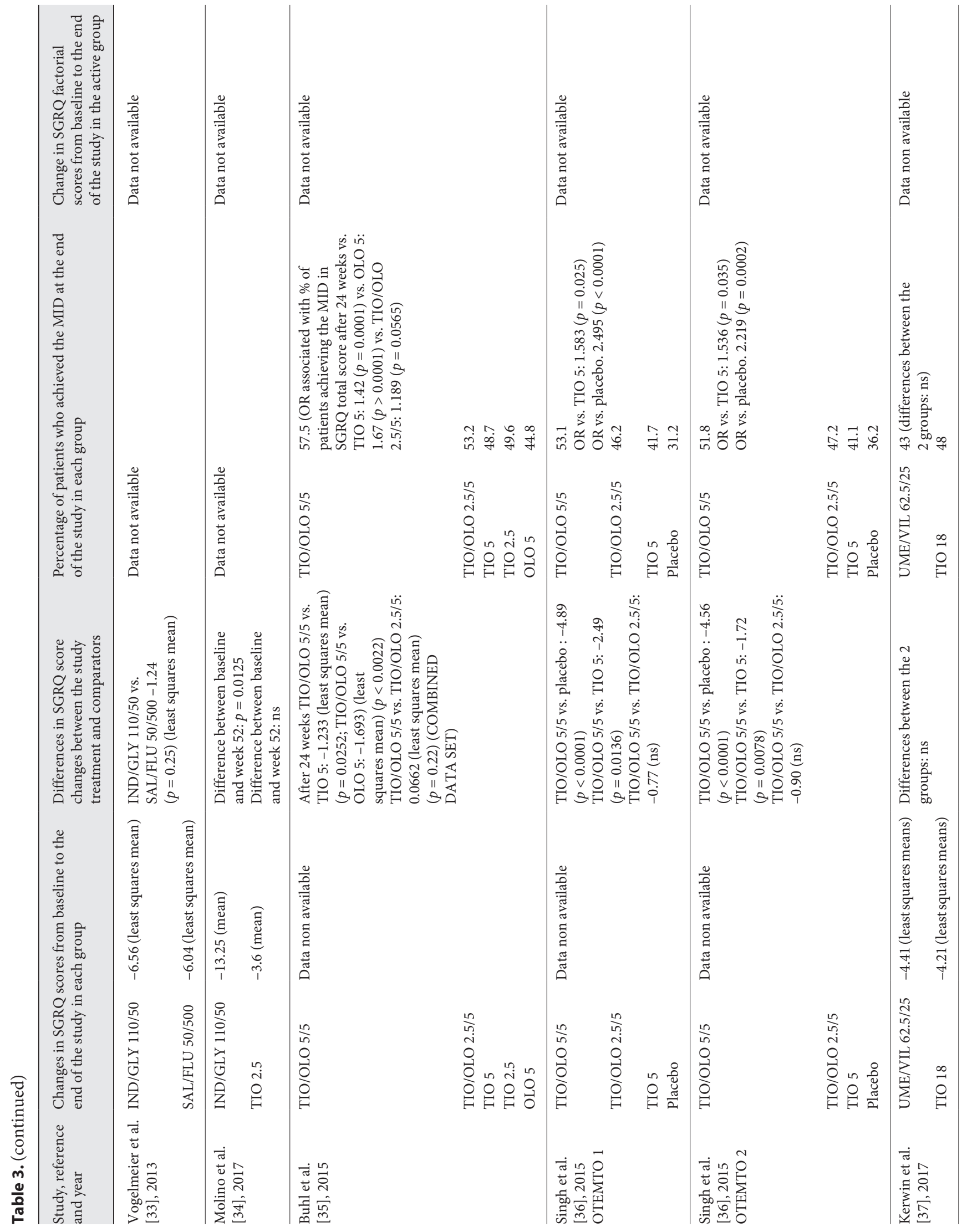




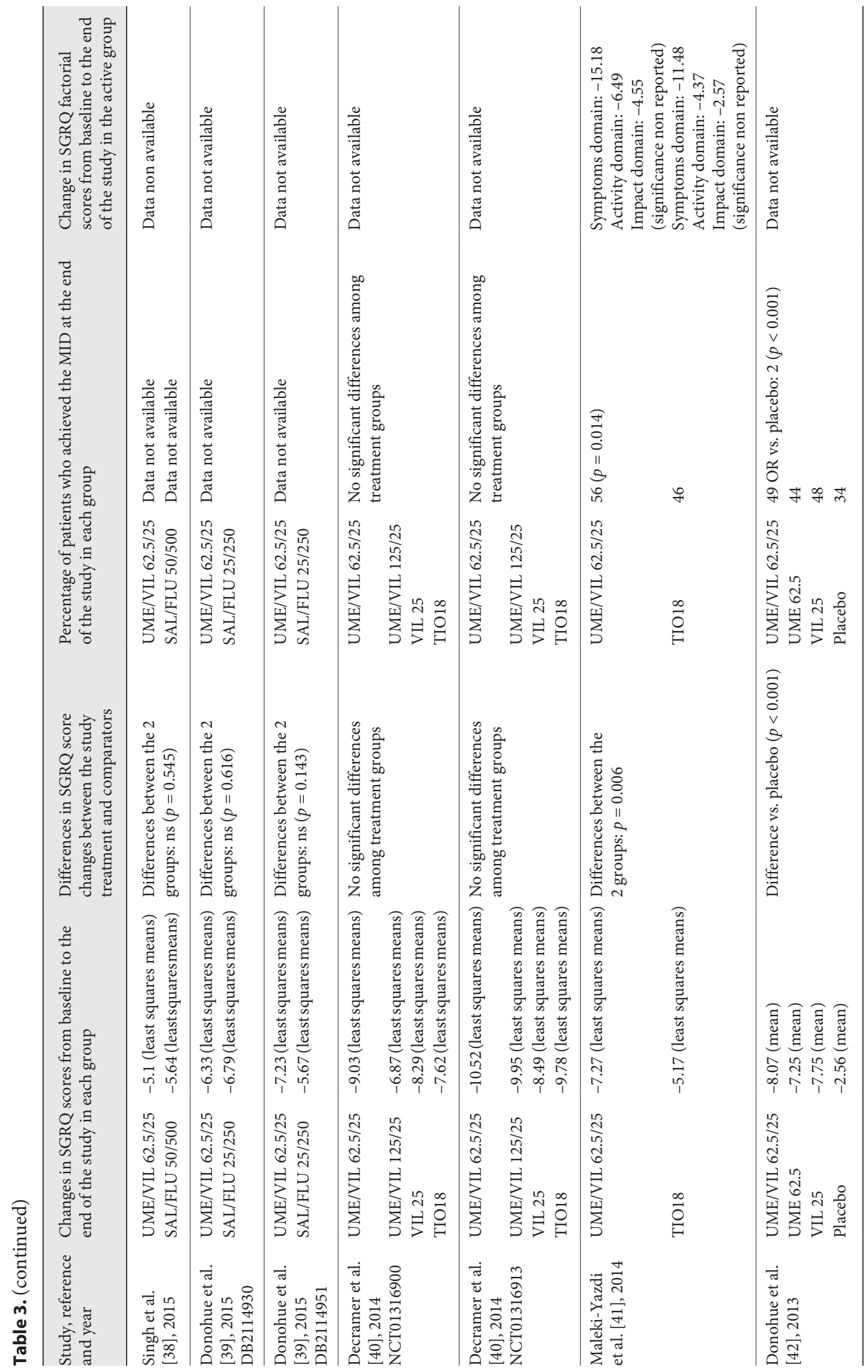




\section{Discussion}

In this review, we analyzed 22 articles, reporting 28 RCTs. A consistent improvement in HRQoL with LABA/ LAMA FDC when compared to placebo has been shown, while the average change when compared to LAMA or LABA monocomponents was significantly better in 11 out of 24. Interestingly, of 6 RCTs having LABA/ICS as comparators, only 1 (IND/GLY) showed a significant improvement in HRQoL. Three out of four studies with ACL/FOR used placebo as one of the comparators with $1 / 3$ showing no significant difference, and the remaining showing significantly better results with the difference reaching MID [25]. Two (out of 3) RTCs with GLY/FOR compared the combination with placebo showing a significantly better improvement in one (Pinnacle 1) with a difference not reaching MID [26] and no significant difference in the other (Pinnacle 2) [26]. For the IND/GLY combination 3 papers (out of 8) reported results compared to placebo arm and all of them showed a significantly better SGRQ scores for the combination. However, the average difference did not reach MID in any of the 3 studies. For TIO/OLO, 2 (out of 3) reported significantly better SGRQ scores, reaching MID in both cases. For the UME/VIL combination, out of 9 RCTs, only one had a placebo arm, reporting a significantly better improvement (reaching MID) for the combination. Only 6 studies used other HRQoL questionnaires (EQ-5D and/or CAT) and no one detected significant differences. Reported studies show significant methodological heterogeneity, in terms of duration, number of treatment arms, and comparators. Although in all but one studies SGRQ was used as the measure of HRQoL, a significant heterogeneity exists in reporting the outcomes for HRQoL measures, with only 2 papers reporting SGRQ component analysis. In 9 out of 12 trials, the improvement from baseline until the end of trial exceeded the MID. Several problems were found in interpreting the published results. In 7 articles, data were not available in the source materials and only the $\%$ of patients exceeding MID, or ORs for exceeding MID were published, although these data support the previous conclusion. This could be the consequence of HRQoL not being the primary outcome in these studies, but even in the single study where HRQoL was the primary outcome, data about the change in SGRQ from baseline until the end of trial were not available [36]. Although a weak association $\left(R^{2}=0.21\right)$ exists between the level of bronchodilation and HRQoL/HS outcomes [17], it could be expected that less hyperinflation, lower level of symptoms and dyspnea, comparable incidence of adverse events, and dosing from a single device could provide such a consistent effect for different LABA/LAMA FDCs. Furthermore, there is a significant heterogeneity regarding the duration of trials, ranging from 8 to 64 weeks, although changes in HRQoL after initial improvement with long-acting bronchodilators show a stable effect. Based on the published RCTs, it is not possible to compare the results of different LABA/ LAMA combinations. The only head-to-head comparison between UME/VIL and TIO/OLO fixed combinations showed a significantly better improvement in HRQoL (measured by CAT) for UME/VIL after 4 weeks but not after 8 weeks, suggesting possible marginal difference in the effect on the HRQoL with the stabilization of the effect after 8 weeks of treatment [18]. Although data when analyzed together and despite the significant heterogeneity of the studies do point in the same direction, toward improvement in HRQoL outcomes with LABA/LAMA FDCs versus comparators, there are some interesting differences that should be mentioned. These differences could point into some clinical aspects that could be relevant for some patient groups (phenotypes) and could lead the treatment decisions. This is especially relevant in the light of discordant results for different facets (lung function, exacerbations, PROs) of the disease [17]. The first one of clinical interest is the finding that when LAMA was the comparator to LABA/LAMA FDCs in 10 out of 19 RCTs the combination showed a significant improvement in HRQoL, while when LABA was a comparator the odds were the opposite. Only in 1 out of 13 RCTs, the combination showed a significant improvement in HRQoL. The same odds were seen with LABA/ICS as a comparator. We can only speculate that the second finding could be the consequence of LABA being the part of the combination or that it was associated also with ICS. However, these findings could point out that if the primary goal of treatment change in a patient with COPD is to improve HRQoL change from LABA or LABA/ICS to LABA/LAMA FDC would probably not be beneficial. This speculation certainly deserves well-designed RCTs. Other recently published reviews on the efficacy of LABA/LAMA FDCs [15, $16,48,49]$ were not specifically focused on HRQoL and HS but also analyzed these outcomes. The results of our review and the other recent reviews $[15,48]$ show that studies powered to detect differences in HRQoL/HS as primary outcome are needed. More head-to-head comparisons of LABA/LAMA products would improve clinical relevant insights as well. Additionally, current data depend on the quality of the used instruments to assess PROs. Commonly used instruments, like SGRQ, CAT, or Transition Dyspnea Index, lack certain domains of great 
importance to patients with COPD, such as mobility, fatigue, anxiety, depression, social functioning, and sleep. We pointed out this aspect in a previous review about HRQoL/HS outcomes with long-acting bronchodilators in COPD, but the goal still needs to be reached [4]. This issue could be solved by the usage of a standardized set of tools to assess also these important PROs domains. Furthermore, to allow proper meta-analyses and give researchers the right opportunity to pull up and analyze the data and reduce heterogeneity, a standardized set and format of data should be proposed and agreed upon (at least for the supplementary set of data that is published online). All this will give us reassurance that we will have enough high-quality scientific data to better assess and understand outcomes that are of primary concern for patients.

\section{Acknowledgments}

Authors would like to thank Interasma (Global Asthma Associations - AAA) and Interasma European Scientific Network (INESnet) for technical support.

\section{Disclosure Statement}

The authors report no conflicts of interest.

\section{References}

1 Global Strategy for the Diagnosis, Management and Prevention of COPD, Global Initiative for Chronic Obstructive Lung Disease (GOLD) 2017. http://goldcopd.org.

2 Barr RG, Bourbeau J, Camargo CA, et al: Tiotropium for stable chronic obstructive pulmonary disease: a metaanalysis. Thorax 2006;61:854-862.

3 Tashkin DP, Donohue JF, Mahler DA, et al: Effects of arformoterol twice daily, tiotropium once daily, and their combination in patients with COPD. Respir Med 2009;103:516-524.

4 Braido F, Baiardini I, Cazzola M, Brusselle G, Marugo F, Canonica GW: Long-acting bronchodilators improve health related quality of life in patients with COPD. Respir Med 2013; 107:1465-1480.

5 Vogelmeier C, Kardos P, Harari S, et al: Formoterol mono- and combination therapy with tiotropium in patients with COPD: a 6-month study. Respir Med 2008;102:15111520.

6 van Noord JA, Aumann JL, Janssens E, et al: Combining tiotropium and salmeterol in COPD: effects on airflow obstruction and symptoms. Respir Med 2010;104:995-1004.

7 Mahler DA, D'Urzo A, Bateman ED, et al: Concurrent use of indacaterol plus tiotropium in patients with COPD provides superior bronchodilation compared with tiotropium alone: a randomised, double-blind comparison. Thorax 2012;67:781-788.

8 Cazzola M, Molimard M: The scientific rationale for combining long-acting beta2-agonists and muscarinic antagonists in COPD. Pulm Pharmacol Ther 2010;23:257-267.

9 Cazzola M, Di Marco F, Santus P, Boveri B, Verga M, Matera MG, Centanni S: The pharmacodynamic effects of single inhaled doses of formoterol, tiotropium and their combination in patients with COPD. Pulm Pharmacol Ther 2004; 17:35-39.

10 Veogelmeier C, Hederer B, Glaab T, et al: Tiotropium versus salmeterol for the preven- tion of exacerbations of COPD. N Engl J Med 2011;364:1093-1103.

11 Decramer ML, Chapman KR, Dahl R, et al: Once-daily indacaterol versus tiotropium for the patients with severe chronic opstructive pulmonary disease (INVIGORATE): a randomised, blinded, parallel-group study. Lancet Respir Med 2013;1:524-533.

12 van Noord JA, Aumann JL, Janssens E, Smeets JJ, Verhaert J, Disse B, Mueller A, Cornelissen PJ: Comparison of tiotropium once daily, formoterol twice daily and both combined once daily in patients with COPD. Eur Respir J 2005;26:214-222.

13 Wang J, Jin D, Zuo P, Wang T, Xu Y, Xiong $\mathrm{W}$ : Comparison of tiotropium plus formoterol to tiotropium alone in stable chronic obstructive pulmonary disease: a meta-analysis. Respirology 2011;16:350-358.

14 Farne HA, Cates CJ: Long-acting beta2-agonist in addition to tiotropium versus either tiotropium or long-acting beta2-agonist alone for chronic obstructive pulmonary disease. Cochrane Database Syst Rev 2015;10: CD008989.

15 Calzetta L, Rogliani P, Matera MG, Cazzola M: A systematic review with meta-analysis of dual bronchodilation with LAMA/LABA for the treatment of stable COPD. Chest 2016; 149:1181-1196.

16 Lopez-Campos JL, Calero-Acuña C, MárquezMartín E, Quintana Gallego E, CarrascoHernández L, Abad Arranz M1, Ortega Ruiz F: Double bronchodilation in chronic obstructive pulmonary disease: a crude analysis from a systematic review. Int J Chron Obstruct Pulmon Dis 2017;12:1867-1876.

17 Patrick DL, Burke LB, Powers JH, Scott JA, Rock EP, Dawisha S, et al: Patient- reported outcomes to support medical product labeling claims: FDA perspective. Value Health 2007;10(suppl 2):S125-S137.

18 Feldman GJ, Sousa AR, Lipson DA, Tombs L, Barnes N, Riley JH, Patel S, Naya I, Compton
C, Alcázar Navarrete B: Comparative efficacy of once-daily umeclidinium/vilanterol and tiotropium/olodaterol therapy in symptomatic chronic obstructive pulmonary disease: a randomized study. Adv Ther 2017;34:25182533.

19 Jones PW, Quirk FH, Baveystock CM, Littlejohns P: A self-complete measure of health status for chronic airflow limitation. The St. George's Respiratory Questionnaire. Am Rev Respir Dis 1992;145:1321. e 7.

20 Jones PW; The Nedocromil Sodium Quality of Life Study Group: Quality of life, symptoms, and pulmonary function in asthma: long-term treatment with nedocromil sodium examined in a controlled multicentre trial. Eur Respir J 1994;7:55-62.

21 Jones PW. Interpreting thresholds for a clinically significant change in health status in asthma and COPD. Eur Respir J 2002;19:398404.

22 Jones PW; The Nedocromil Sodium Quality of Life Study Group: Quality of life, symptoms, and pulmonary function in asthma: long-term treatment with nedocromil sodium examined in a controlled multicentre trial. Eur Respir J 1994;7:55-62.

23 Jones PW: Interpreting thresholds for a clinically significant change in health status in asthma and COPD. Eur Respir J 2002;19:398 404.

24 D'Urzo A, Rennard S, Kerwin E, Donohue JF, Lei A, Molins E, et al: A randomised doubleblind, placebo-controlled, long-term extension study of the efficacy, safety and tolerability of fixed-dose combinations of aclidinium/ formoterol or monotherapy in the treatment of chronic obstructive pulmonary disease. Respir Med 2017;125:39-48.

25 Vogelmeier C, Paggiaro PL, Dorca J, Sliwinski P, Mallet M, Kirsten AM, et al: Efficacy and safety of aclidinium/formoterol versus salmeterol/fluticasone: a phase 3 COPD study. Eur Respir J 2016;48:1030-1039. 
26 Singh D, Jones PW, Bateman ED, Korn S, Serra C, Molins E, et al: Efficacy and safety of aclidinium bromide/formoterol fumarate fixeddose combinations compared with individual components and placebo in patients with COPD (ACLIFORM-COPD): a multicentre, randomised study. BMC Pulm Med 2014;14: 178.

27 D'Urzo AD, Rennard SI, Kerwin EM, Mergel V, Leselbaum AR, Caracta CF, et al: Efficacy and safety of fixed-dose combinations of aclidinium bromide/formoterol fumarate: the 24-week, randomized, placebo-controlled AUGMENT COPD study. Respir Res 2014; 15:123.

28 Martinez FJ, Rabe KF, Ferguson GT, Fabbri LM, Rennard S, Feldman GJ, et al: Efficacy and Safety of Glycopyrrolate/Formoterol Metered Dose Inhaler Formulated Using CoSuspension Delivery Technology in Patients With COPD. Chest 2017;151:340-357.

29 Hanania NA, Tashkin DP, Kerwin EM, Donohue JF, Denenberg M, O'Donnell DE, et al: Long-term safety and efficacy of glycopyrrolate/formoterol metered dose inhaler using novel Co-Suspension Delivery Technology in patients with chronic obstructive pulmonary disease. Respir Med 2017;126:105-115.

30 Wedzicha JA, Banerji D, Chapman KR, Vestbo J, Roche N, Ayers RT, et al: IndacaterolGlycopyrronium versus Salmeterol-Fluticasone for COPD. N Engl J Med 2016;374: 2222-2234.

31 Zhong N, Wang C, Zhou X, Zhang N, Humphries M, Wang L, et al: LANTERN: a randomized study of QVA149 versus salmeterol/fluticasone combination in patients with COPD. Int J Chron Obstruct Pulmon Dis 2015;10:1015-1026.

32 Mahler DA, Kerwin E, Ayers T, FowlerTaylor A, Maitra S, Thach C, et al: FLIGHT: Efficacy and Safety of QVA149 (Indacaterol/Glycopyrrolate) Versus its Monocomponents and Placebo in Patients with COPD. Am J Respir Crit Care Med 2015;192:1068-1079.

33 Bateman ED, Ferguson GT, Barnes N, Gallagher N, Green Y, Henley M, et al: Dual bronchodilation with QVA149 versus single bronchodilator therapy: the SHINE study. Eur Respir J 2013;42:1484-1494.

34 Wedzicha JA, Decramer M, Ficker JH, Niewoehner DE, Sandstrom T, Taylor AF, et al: Analysis of chronic obstructive pulmonary disease exacerbations with the dual bronchodilator QVA149 compared with glycopyrronium and tiotropium (SPARK): a randomised, double-blind, parallel-group study. Lancet Respir Med 2013;1:199-209.

35 Vogelmeier CF, Bateman ED, Pallante J, Alagappan VK, D'Andrea P, Chen $\mathrm{H}$, et al: Efficacy and safety of once-daily QVA149 compared with twice-daily salmeterol-fluticasone in patients with chronic obstructive pulmonary disease (ILLUMINATE): a randomised, double-blind, parallel group study. Lancet Respir Med 2013;1:51-60.

36 Molino A, Simioli F, Stanziola AA, Mormile M, Martino M1, D'Amato M: Effects of combination therapy indacaterol/glycopyrronium versus tiotropium on moderate to severe COPD: evaluation of impulse oscillometry and exacerbation rate. Multidiscip Respir Med 2017;12:25.

37 Buhl R, Maltais F, Abrahams R, Bjermer L, Derom E, Ferguson G, et al: Tiotropium and olodaterol fixed-dose combination versus mono-components in COPD (GOLD 2-4). Eur Respir J 2015;45:969-979.

38 Singh D, Ferguson GT, Bolitschek J, Gronke L, Hallmann C, Bennett N, et al: Tiotropium + olodaterol shows clinically meaningful improvements in quality of life. Respir Med 2015;109:1312-1319.

39 Kerwin EM, Kalberg CJ, Galkin DV, Zhu CQ, Church A, Riley JH, et al: Umeclidinium/ vilanterol as step-up therapy from tiotropium in patients with moderate COPD: a randomized, parallel-group, 12-week study. Int J Chron Obstruct Pulmon Dis 2017;12:745755.

40 Singh D, Worsley S, Zhu CQ, Hardaker L, Church A: Umeclidinium/vilanterol versus fluticasone propionate/salmeterol in COPD: a randomised trial. BMC Pulm Med 2015;15: 91.

41 Donohue JF, Worsley S, Zhu CQ, Hardaker L, Church A: Improvements in lung function with umeclidinium/vilanterol versus fluticasone propionate/salmeterol in patients with moderate-to-severe COPD and infrequent exacerbations. Respir Med 2015;109:870881.

42 Decramer M, Anzueto A, Kerwin E, Kaelin T, Richard N, Crater G, et al: Efficacy and safety of umeclidinium plus vilanterol versus tiotropium, vilanterol, or umeclidinium monother- apies over 24 weeks in patients with chronic obstructive pulmonary disease: results from two multicentre, blinded, randomised controlled trials. Lancet Respir Med 2014;2:472486.

43 Maleki-Yazdi MR, Kaelin T, Richard N, Zvarich M, Church A: Efficacy and safety of umeclidinium/vilanterol $62.5 / 25 \mathrm{mcg}$ and tiotropium $18 \mathrm{mcg}$ in chronic obstructive pulmonary disease: results of a 24-week, randomized, controlled trial. Respir Med 2014;108:17521760.

44 Donohue JF, Maleki-Yazdi MR, Kilbride S, Mehta R, Kalberg C, Church A: Efficacy and safety of once-daily umeclidinium/vilanterol 62.5/25 mcg in COPD. Respir Med 2013;107: $1538-1546$

45 Jones PW, Harding G, Berry P, et al: Development and first validation of the COPD Assessment Test. Eur Respir J 2009;34:648. e54.

46 CAT Development Steering Group: COPD assessment test $d$ health care professional user guide. http://www.catestonline.org/images/ UserGuides/CATHCPUser\%20guideEn.pdf (accessed December 5, 2017).

47 Kon SS, Canavan JL, Jones SE, Nolan CM, Clark AL, Dickson MJ, Haselden BM, Polkey MI, Man WD. Minimum clinically important difference for the COPD Assessment Test: a prospective analysis. Lancet Respir Med 2014; 2:195-203.

48 EuroQoL Group: EuroQoL: a new facility for the measurement of heath-related quality of life. Health Policy 1990;16:199-208.tute, New England Medical Center; 1993.

49 Tsiplova K, Pullenayegum E, Cooke T, Xie F: EQ-5D-derived health utilities and minimally important differences for chronic health conditions: 2011 Commonwealth Fund Survey of Sicker Adults in Canada. Qual Life Res 2016; 25:3009-3016.

50 Lopez-Campos JL, Calero-Acuña C, Márquez-Martín E, Quintana Gallego E, Carrasco-Hernández L, Abad Arranz M, Ortega Ruiz F: Double bronchodilation in chronic obstructive pulmonary disease: a crude analysis from a systematic review. Int J Chron Obstruct Pulmon Dis 2017;12:18671876.

51 Tariq SM, Thomas EC: Maintenance therapy in COPD: time to phase out ICS and switch to the new LAMA/LABA inhalers? Int J Chron Obstruct Pulmon Dis 2017;12:1877-1882. 